\title{
The Application of Mohammed Ayoob's Subaltern Realist Theory to both Internal and External Security Threats of Ethiopia: A Short Reflections
}

\author{
Mulugeta Tesfaye Teshome* \\ Wollo University, program of Peace and Development Studies, Ethiopia
}

*Corresponding Author: Mulugeta Tesfaye Teshome, Wollo University, program of Peace and Development Studies, Ethiopia

\begin{abstract}
Subaltern is the postcolonial approach to study international relation from the week states' perspective. It is the offspring of realism which focuses on internal vulnerability is a major source of insecurity. The article is applied as a framework to explain security threats in Ethiopia and reviewed papers that are write on Ethiopian national security. This short article reviewed and classified the Ethiopian security threats as internal and external. By consulting the bulk of literature and my daily academic talk with colleagues; Poverty, famine, recurrent and drought, National integrity (consolidating Ethnic conflict federalism), The danger of succession and state failure, Democratization and election issues are identified as Internal security threats. On the other hand Terrorism, Proliferation of arms, Fragile Relation with Neighboring governments, Nile politics and neighboring countries' spreading civil wars are claimed to be External security threats. To sustain the sparkle of democracy and development achieved throughout the last decades, it is imperative to work aggressively and focus on the country's internal vulnerability.
\end{abstract}

Keywords: Ethiopia, Realist, Security, Subaltern, Threats

\section{INTRODUCTION}

Subaltern is a postcolonial approach began by south Asia historiographer, particularly in India which includes groups who are socially, politically and geographically outside of the hegemonic power structure of the colony and the colonial homeland. In simple words, history told from below from those excluded from political representation (http: //www.scnet.ucla.edu/history/lal/subalter.html)

Mohammed Ayoob's approach of subaltern realism mainly and or differently focuses on international relations of the weak and poor states that are not yet part of international system beyond the legal sense. He begins with the premise that international inequality lies in the heart of theorizing IR theories, policy making process and state practice (Ayoob, 1998). To break this vicious circle problem he suggests an alternative theory which could effectively explain the origin of major conflictin international system and variable which determines the behavior of most postcolonial states domestically and externally by constituting the tradition of classical realism, historical sociological literature and order of international society(ibd).

Mohammed Ayoob gives substantive theory which fill the gap that neorealism and neoliberalism fail collect inadequate data historically and geographically fit to the context in theorizing the third world conflict. For him, the third world states in general and in Ethiopia in particular security and state behavior is rooted and need to be analyzed in to two important historical and contemporary contexts. These are:

A. rapid decolonization and state formation,

B. physical and normative intrusion of outsider in the name of international law.

Based on this perspective Ethiopia has both internal and external threats that has to be analyzed in Ayoob's subaltern realism. As explained by Buzan and Weaber in their work "Regions and powers; The structure of international security" Ethiopia as the pre-modern state she suffered from low levels of sociopolitical cohesion and poorly developed structures of government with the threat of being 
neglected and allowed to fall in internal chaos and vulnerability before 1991 and after1991(www. cambrig.org/9780521814126 ).

This long lasting internal threat faces the country could not explained by Eurocentric theories because of their limitation mentioned above. In the following pages I am going to illustrate how Mohammed Ayoob's theory is applicable to those cases.

\section{ETHIOPIA BEFORE 1991}

Ethiopia as a third world state, the international phenomenon(two world wars, bipolarity, cold war and end of cold war) that has been happening in the last half century affect its behavior which is reflected on her domestic and external threat. As mentioned above the rapid decolonization and state formation however not applicable to Ethiopia, she was in equal trend of nation (state) building stage with associated setbacks after several internal ups and downs under different monarchical rule (Makakis and Nega, 1986). .

In 1974 the imperial regime dethroned the leftist militant and join the communist camp. The domestic threat by then was create a legitimate government, effective control over the state, economic selfreliance (sustainable economic development), the problem of rule of law, the use of balanced violence, potential state failure and a danger of secession (Makakis and et al, 1986).

The Dergeau regime respond to those problems aggressively in the name of protecting the fruit of socialist revolution. The economy was highly dependent on the aid of socialist country like USSR and China. This economic aid was accompanied by nationalization and command fiscal and financial policy which leads to ineffective control of the economy at all. Above all to suppressed opposition that mushroomed here and there because of the military regime use excessive force in the form of summary execution. The arbitrary rule of the regime finally lead the Ethiopian people to inter in armed struggle. Among the armed group some were in need of succession like TPLF, ELF, EPRP, EDU and OLF (http://www.ethiopiantreasures.co.uk/pages/derg.htm). This was happened under the great international pressure ideological intervention/aid by east-west rivalry by then. This international pressure fueled by boarder clash with Somalia and neighboring sponsored sporadic guerilla fighters like Sudan Republic and Egypt were the major countries who support the armed groups in response to Ethiopians support for south Sudan movement and regional hegemony over the red sea respectively for Sudan and Egypt.

\section{ETHIOPIA AFTER 1991}

By 1991 EPRDF came to power by overthrowing the military Dergeau regime with many political, ideological, and geographical changes than the previous Ethiopia. The EPRDF transitional government gives recognition to the independence of Eritrea and such recognition left Ethiopia landlocked country. The Eritrean independence was easy and not procedural except the bloodshed that happened during the civil war it was because the time of independence (binging of cold war).

Because of the destruction of the camp of communist camp in 1989 the country's orientation become to the free market economy which is associated with privatization and then fashion of economic liberalization as Ayoob explained it. After this transitional period the Ethiopian security threats are still both external and internal, was historical and contemporary. Internal threats Ethiopia are more imminent than the external one. I select some of them to discuse.

The Internal Threats are:

- Poverty, famine, recurrent and drought

- National integrity (consolidating Ethnic conflict federalism),

- The danger of succession and state failure,

- Democratization, election

External threats are:

- Terrorism, Proliferation of arms,

- Fragile Relation with Neighboring governments, 
- Nile politics.

\subsection{Poverty, Famine, Recurrent and Drought}

Poverty is a deep national threat that endanger the security of the state and security of a society in general. Even if the EPRDF gave promise to help the people of Ethiopia to escape the trap of poverty, it was not easy to fulfill it. It was because, the long lasting environmental degradation, recurrent drought and the neoliberal pressure to privatize the national companies owned by the state which causes a number of social chaos like unemployment and lose of state revenue. The late Ethiopian premium Melese argued the forced privatisation of market for multinational firms also dominate the infant national companies. But because of selective privatization policy and developmental state approach saved Ethiopia from total destruction like other sub-Saharan states. In this policy option Ethiopia suffered from absence of sufficient aid and loan for development project. But the rise of China and India save Ethiopia from this disastrous effect of normative intrusion of neo-liberal countries (http://www.search.ask.com/search?q=speach+of+meles+in+colombia+u)Step by step Ethiopia scored around $11 \%$ economic growth for in the past five consecutive years. But still Ethiopia is suffering from trade deficit because of the Ethiopian agricultural products (coffee and chat) including hide and skin price determined by the importer. That is why the Mohammed Ayoob's theory of subaltern says cooperation under anarchical international system hurts the poor and weak cause domination by the rich and developed countries.

\subsection{National Integrity (Consolidating Federalism)}

The other big security issue is national integrity (state building). State building in Ethiopia is a big concern to federalism and ethnic conflict. Historically, the major causes of conflict in Ethiopia are related to access to state power, competition over scares resource and others. The misguided policy of Ethiopian regime and geopolitical condition of Horn of Africa has implications with Ethiopian ethnic group relation. Despite the adoption of federalism since 1991 the status of ethnic conflict management is still weak because of different reasons. The following are among others Weak participation of civil society, inadequate procedure such as early warning and conflict prevention, and Lack of democratic culture (Merera, 2004).

In addition to this, many opposition scholars of EPRDF warned Ethiopian federalism is very similar to the former Yugoslavian federalism. For example of Ethiopian and the former Yugoslavian federalism is characterized by one dominant party (TPLF/ EPRDF and LCY), contradictory events, socialist oriental and federalism, blurred line between party and state and centralized federalism, and absence of separation of power between the three branches of government. Divide Turton also indicated that Ethiopian ethnic federalism is at a greater risk of failure because of non- sufficient federalism. (Turton, 2006)

\section{DEMOCRATIZATION}

Merera explained in his work published in the book "The Quest for Peace in Africa" under the title "Ethiopia: Constraint democratization process" in 1991 TPLF/ ERDF took power by giving promise to bring about durable peace, democratic governance, and economic development by creating egalitarian nation state. This time was dual transformation for Ethiopia, i, e. transformation from ethnically dominated empire to nation state and from authoritarian to democratic governance. The leader proclaim that it was the end of hundred years suffering of under oppressive feudal system and brutal military regime which was seen as the advent of new history for its habitants (Merera, 2004).

Despite those premises, there are great discrepancies between what was promised and reality on the ground. Our elections has been held, various policy initiatives has been taken but the state of Ethiopia is still centralized. So, groups take gun by quoting the radicalism quote, the true independence was came through the barrel of gun. Now a days, eight armed groups fight Ethiopian government (Merera, 2004).

Generally the Ethiopian foreign affairs and national security policy and strategy clearly lay down that the country's main security threats internal, that is poverty which leads the state to collapse or absence of democracy and good governance which will increase vulnerably to external threat. This is what Mohammed Ayoob wants to indicate. Internal security needed to give priority. The more the country 
internally coherent, the more externally secured. The country's relation with other states primarily based on economic relation either the state is hostile or friendly. The government is aware of the consequence coming from economic success and failure (Ayoob, 2002).

\section{EXTERNAL THREAT}

As I stated above Ethiopia indeed faced external threated like terrorism, proliferation of arms and spillover effects of neighboring country conflict and boarder issues. The achievement of withstanding domestic threat, poverty, shelled the country from setbacks that face in regional relation, bilateral relation and multilateral relation. For example, Ethiopia plays a pivotal role in IGAD. First international transformation of IGAD is a hand craft of Ethiopian leaders in high percentage Ethiopia participate in building forum of Somalia, peace talk in south Sudan and making an effort to bring back Eritrean in regional responsibility to rejoin IGAD. Ethiopia tries to make IGAD the building block of future USA. Ethiopia behaves hostile towards extremist tendency of nation building around her boundary. Example, Ethiopia she sponsored armed struggle in Eritrea, transitional government in Somalia.

As Abebe Kifleyesus indicated, the relation between Eritrea and Ethiopia in his work perception of pacifism: good fences makes good neighbor that cross-border community of Eritrea and Ethiopia have long shared common culture and decent which bound them together. This is true that those traditions are ethical forces that the more powerful than any other legal order, administrative directives and impositions. It allowed to flourish and function the traditional institutions can be a positive force in establishing lasting peace (Abebe, 2004).

To sum up, Ayoob's subaltern realist gives explanation historically and geographically fit theory in understanding Ethiopian behavior towards domestic and external threats. As his explanation there is high need to respect the international norm and Westphalia system to protect them from unwanted intervention (Ayoob, 2002). Ethiopia exactly did it to maintain here relationships with the "international police".

\section{REFERENCES}

[1] Abebe,K .2004. The Quest for Peace in Africa. In Nhema,G,(Ed). Federalism: Some trend of Conflict and their Management in Ethiopia. OSSREA, Adis Abeba.

[2] Asnake,K .2004. The Quest for Peace in Africa. In Nhema,G, (Ed). Perception of Pacifism: Renewed Ayoob,M. 2002. Inequality and Theorizing in International Relation: the case for subaltern realism.

[3] Blackwellpublishing, Malden Comparative Perspective (pp. 1-31). Oxford: James Curry. Ethiopia. OSSREA, AddisAbaba.

[4] Merera Gudina.2004. The Quest for Peace in Africa.In Nhema,G, (Ed). Perception of Pacifism: Renewed Markakis,J. and Nega,A.1986.Class and Revolution in Ethiopia. Red Sea press, New Jersey.

[5] Respect with the wisdom of "Good fiance make Good Neighbors" between Eritrea and Turton, D. (2006). Introduction. In D. Turton, Ethnic Federalism: The Ethiopian Experience in https://openaccess. leidenuniv. nl/bitstream/hadle/1887/13839/chapter\%2520two.pdf\%3Fsequence\%3D13http://www.ethiopiantreassures. co.uk/pages/derg.htm

Citation: Mulugeta Tesfaye Teshome. "The Application of Mohammed Ayoob's Subaltern Realist Theory to both Internal and External Security Threats of Ethiopia: A Short Reflections" International Journal of Political Science (IJPS), vol 5, no.3, 2019, pp. 70-73. doi: http://dx.doi.org/10.20431/2454-9452.0503006.

Copyright: () 2019 Authors. This is an open-access article distributed under the terms of the Creative Commons Attribution License, which permits unrestricted use, distribution, and reproduction in any medium, provided the original author and source are credited. 